\title{
Utilization of the Natural Rubber for Pipe Rehabilitation Construction in Urban Area
}

\author{
Atee Amprai ${ }^{1}$, Pichai Niwasuwan ${ }^{1}$, Nattagarn Sangtaweeptaweekij ${ }^{1}$, Sideth Prum ${ }^{2}$, Gerard Duggan $^{3}$, \\ Thanarat Poorat ${ }^{1}$ and Nalinee Jumnongpol ${ }^{1}$ \\ ${ }^{1}$ Metropolitan Waterworks Authority \\ 400 Prachachuen Road, Laksi, Bangkok, Thailand \\ atreepro@yahoo.com, nalinee.j@mwa.co.th,kmut51@gmail.com, kook_civil@yahoo.com \\ ${ }^{2}$ Suvannaphum Investment Co., Ltd \\ Sangkat BoengKak II, Phnom Penh, Cambodia \\ sidethprum@gmail.com \\ ${ }^{3}$ Civil Engineering Technical Advisor, KBR \\ Perth, Australia \\ duggan.Gerard@jkc-lng.com
}

\section{Extended Abstract}

A water distribution network is one of the key basic infrastructure systems which is used to serve the population sufficient quantity of good quality water [1]. Due to Infrastructure development and urban growth, most of pipe rehabilitation areas and old pipe line systems are affected by other infrastructure systems such as electrical lines, pedestrian overpass structure, drainage systems and other substructures [2]. The changing of environment such as construction nearby pipeline, flooding, transportation management etc. are important factors for the pipe failures and buffer zone. Especially, the record shows that problems of buffer areas have more affected to fracture leakage and water losses than other factors in the Nontha Buri service area. Normally, the failures causes can provide to 1) potential of pipe materials, 2) water supply operations system and 3) external forces.

The problem of buffer zone is a predominant factor causing the pipe failures from external forces. Several of unexpected forces from surroundings can be directly transfer to pipe surface due to the problems of buffer zone cannot decrease the pressure distribution on the pipe. The improvement of buffer zone is an important factor for pipe failures reduction. The physical properties of standard and natural materials were considered to be essential for the buffer zone in order to repair and decrease the pipe leakages. The force absorption and flexibility of material are important properties for buffer zone improvement, pipe rehabilitation, and the solutions of the old pipe repairing.

This paper aims to study the usage of natural rubber called Standard Thai Rubber (STR) in reducing the stress distribution affecting the pipeline. Three types of STR were used in this study; which are STR 5, STR 10, and STR CV. STR CV has been adjusted the Constant Viscosity Rubber (CV) with a Hydroxylamine hydrochloride content of $0.15 \%$ by weight. The simulation model of STR plate shows that the stress was reduced in both vertical and horizontal stress distribution for the case studies by a factor of around 3 and 4 times of normally repairing techniques respectively, of which STR CV produce the best performance.

At the observation period, water loss has been reduced around $1.5 \%$ or $86,000 \mathrm{~m}^{3}$ per month of Billed Authorized Consumption. The natural rubber product from agriculture that has not been industrially manufactured has a good efficiency potential to be used for decreasing the stress distribution in buffer zone of pipe rehabilitation.

\section{References}

[1] A. Tongchew, (2017, Feb 15), Challenges in water losses in Thailand Reporting. [Online]. Available: http://www.irdp.org/2015/news_files/226/attachment1.pdf

[2] A. Chiplunkar, K. Seetharam, C. Kheong Tan, (2017, Feb 15), Good Practices in Urban Water Management. [Online]. Available: http://reliefweb.int/sites/reliefweb.int/files/resources/good-practices-urban-watermanagement.pdf 